Syntax Fusion : Jurnal Nasional Indonesia

p-ISSN: $x x x x-x x x x$

e-ISSN : $x x x x-x x x x$

Vol. 1, No. 1, Oktober 2020

\title{
ANALISIS ISI PESAN DAKWAH KISAH DZULQARNAIN DALAM BUKU "30 KISAH TELADAN" KARYA K.H ABDURRAHMAN ARROISI (JILID I)
}

\section{Kurniawan}

\section{Sekolah Tinggi Agama Islam (STAIPI) Bandung}

E-mail: officialkurniawan47@gmail.com

\section{Abstrak}

Dakwah itu tidak selalu harus lewat mimbar akan tetapi kita harus bisa memanfaatkan berbagai sarana yang ada supaya dakwah tidak terbatas ruang dan waktu. Berdakwah bisa dilakukan melalui media tulis, yang sering disebut juga daakwah bil qolam yaitu sarana atau metode penyampaian pesan-pesan dakwah dari Da'i kepada Mad'u melalui media cetak dan salah satunya adalah buku.

Metodologi yang digunakan dalam penelitian ini adalah analisi isi yakni teknik penelitian untuk memperoleh gambaran isi pesan komunikasi dalam buku "30 Kisah Teladan”. Dalam melakukan penelitian ini penulis menggunakan metode bagaimana melihat isi komunikasi secara kualitatif dan bagaimana penulis memaknai isi komunikasi, membaca simbol-simbol serta memaknai interaksi simbolik yang terjadi dalam komunikasi, sehingga dapat menggambarkan secara luas tentang isi kisah Dzulkarnain dari buku "30 Kisah Teladan".

Teori yang digunakan adalah teori Holsty yakni suatu teknik dalam mengambil kesimpulan dengan mengidentifikasi pelbagai karakteristik khusus suatu pesan secara obyektif dan sistematis. Sedangkan yang kualitatif dimana pendekatan ini menggunakan seperangkat tema sebagai pedoman dalam membahas seluruh isi pesan dan mencoba menerangkan bagaimana tema tersebut dikembagkan oleh suatu sumber media dan cenderung untuk meneliti masalah yang tidak mencakup jmlah dan kuantitas.

Isi kisah Dzulkarnain yang terkandung dalam buku "30 Kisah Teladan" ini adalah Pesan Akidah dan Pesan Akhlak. Pesan-pesan didalamnya cenderung membahas Pesan Akhlak. Hal tersebut dikarenakan berkaitan dengan sifat seorang Raja yaitu Dzulkarnain. Maka berdakwah itu tidak hanya harus dimimbar, tetapi berdakwah juga bisa memanfaatkan media yang ada salah satunya adalah buku, karena buku merupakan media dakwah yang cukup efektif.

Kata Kunci: Analisis data, Pesan Dakwah, Kisah Dzulkarnain 


\section{Pendahuluan}

Komunikasi insani (human communication) adalah proses pertukaran pesan yang berlangsung dalam dunia manusia. Karena itu, ia selalu melibatkan manusia, baik dalam konteks intrapersonal, interpersonal, kelompok, maupun massa. Dalam suatu interaksi antarindividu, seperti halnya kegiatan tablig di majelis taklim, pertemuan di tempat kerja, ataupun belajar-mengajar di sekolah, komunikasi sendiri bertujuan menghidupkan suasana interaksi yang berlangsung sehingga diperoleh efek yang maksimal, baik efek kognitif, afektif, yang dilaluinya, komunikasi itu pun terus berkembang, bertransformasi dalam beragam suasana, berubah-ubah wujud sesuai kebutuhan, hingga satu saat manusia harus mengakhiri hayatnya, juga dengan berkomunikasi. Konon, tatkala sakratulmaut menjemput manusia, ada kewajiban manusia lainnya untuk membawa terus berkomunikasi meski hanya menyebut Nama Sang Pencipta, mengulang-ulang ikrar tauhidullah. (Muhtadi, 2012, p. 15)

Komunikasilah yang menjadi pakaian manusia sehari-hari, Komunikasi merupakan kekayaan paling berharga bagi manusia. Komunikasi menjadi media sosialisasi untuk saling bertukar informasi, Lewat komunikasi manusia dapat mengenal dirinya, memahami orang lain, mengerti alam dengan segala isinya, sekaligus mengenal Tuhannya, Bahkan pada tingkat tertentu, komunikasi merupakan fasilitas pembentuk kepribadian seseorang, Dengan segala ragam aktivitasnya, komunikasi juga bisa menjadi ciri masyarakat berperadaban (eivilized society) yang sanggup menembus batas geografis dan kebudayaan, Dengan komunikasi, dunia menjadi terasa kecil, sebagai ruang kehidupan dengan seluruh sudutnya dapat terjamah melalui alat perpanjangan indra yang disebut media. Itulah sebabnya, seorang ilmuwan komunikasi, MelLuhan, melukiskan media sendiri sebagai pesan. (Muhtadi, 2012, p. 16)

Dalam berdakwah, para Da'i atau mubalig umumnya memanfaatkan kemampuan komunikasi yang dimilikinya. Dakwah bil-lisan seolah menjadi satusatunya saluran yang mereka pergunakan dalam menyampaikan pesan-pesan Tuhan untuk dijadikan pegangan dalam kehidupan. Para Da'i ataupun mubalig sesungguhnya tahu kalau ada pendekatan lain dalam mengajak orang berbuat baik, seperti melalui pendekatan Bil-Hal, atau pendekatan uswah. Sejak awal, Al-Qur'an memang telah memperkenalkan sejumlah pendekatan komunikatif dalam dakwah agar mampu menyapa umat melalui kearifan rasa bahasa yang menjadi pakaiannya sehari-hari. AlQur'an juga senantiasa mengingatkan para pengikutnya untuk melakukan dakwah sesuai dengan problema serta kapasitas kebudayaan masyarakat yang dihadapinya. Jika Rasulullah pernah mengisyaratkan bahwa dakwah itu harus dilakukan dengan mempertimbangkan ukuran akal masyarakatnya, 'Alâ Qadri Uqulihim, dakwah juga berarti harus melihat secara cerdas watak kebudayaan setempat di mana dakwah itu dilaksanakan.(Muhtadi, 2012, p. 19)

Sejarah mencatat bagaimana perjuangan dakwah Rasulullah harus berhadapan dengan tantangan kebudayaan yang telah kokoh mempribumi. Padahal, banyak di antara ajaran yang dibawanya dimaksudkan untuk merombak dan meluruskan tata nilai yang telah menjadi anutan masyarakat sehari-hari. Pada satu sisi, Rasulullah harus 
memperkenalkan ajaran baru, dan pada lain sisi Rasulullah juga sulit menghindari kenyataan yang telah kuat mengakar dalam sistem kehidupan masyarakat yang dihadapinya. Di sinilah posisi dilematis medan dakwah sehingga Al-Qur'an sendiri yang langsung memberikan bimbingan bagaimana seharusnya dakwah dilaksanakan.(Muhtadi, 2012, p. 42) Begitupun dengan para pendahulunya, salah satunya adalah Dzulqarnain. Dzulqarnain adalah salah satu nama yang disebutkan didalam Al-Qur'an, Allah swt berfirman:

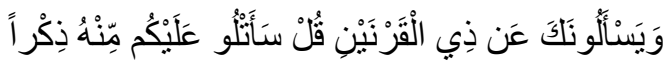 \\ Mereka akan bertanya kepadamu (Muhammad) tentang Dzulkarnain.} Katakanlah: "Aku akan bacakan kepadamu cerita tantangnya". (QS. Al-Kahfi: 83)

Kisah Dzulqarnain ini sangat popular dikalangan umat muslim, namun yang jadi pertanyaan siapakah Dzulqarnain ini? Apakah dia seorang Nabi ataukah sorang hamba yang Shaleh?. Kisah Dzulqarnain sangat erat kaitannya juga dengan kisah Yajuj dan Ma'juj, bangsa yang dipercaya akan keluar menjelang hari kiamat tiba.

Kalau didalam Al-Qur'an Dzulqarnain berdakwah kepada tiga bangsa, yakni bangsa yang berada di Barat, bangsa yang berada di Timur dan bangsa yang berada diantara dua buah gunung.

Dzulkarnain juga adalah seorang raja yang shalih yang telah Allâh Subhanahu wa Ta'ala anugerahi kekuasaan di bumi dan Allâh juga memberikannya ilmu dan hikmah serta Allâh Azza wa Jalla pakaikan kewibawaan padanya, walaupun kita tidak tahu siapakah dia. Ibnu Katsir rahimahulah mengatakan, "Allâh Azza wa Jalla telah memberikan kepadanya kerajaan yang besar dan segala sesuatu yang ada untuk seorang raja, berupa kekuasaan, tentara, peralatan perang dan sarana prasarana yang memadai. Dengannya, dia bisa mengusai dunia, bagian timur maupun baratnya, dan dia menaklukkan berbagai negeri serta menundukkan para penguasa lainnya. Sehingga semua orang berkhidmat untuk kerajaannya. Oleh karena itu, sebagian Ulama berpendapat mengapa dia digelari Dzulqarnain karena kekuasaannya meliputi tempat terbit dan tempat terbenam yaitu timur dan barat bumi." (Https://Almanhaj.or.Id/11476Dzulqarnain-Penguasa-Yang-Adil.Html, n.d.)

Namun yang saya soroti adalah buku yang berjudul 30 Kisah Teladan karya K.H Abdurrahmaan Arroisi. Kita tahu bahwa kegiatan menulis diwujudkan melalui media bahasa tulis, yaitu berupa teks atau wacana tertulis. Dalam hal ini, beliau menuangkan hasil bacaannya kedalam sebuah buku yang berjumlah 12 Jilid, yang setiap jilidnya memuat 30 Kisah Teladan, dari mulai kisah Nabi-nabi dan Rasul-rasul, Para Sahabat Nabi hingga hamba-hamba shaleh yang dipilih oleh Allah salah satunya adalah Raja Dzulkrnain. Dan hal ini pun sejalan dengan para pemikir komunikasi, komunikasi menyarankan bahwa suatu pikiran, suatu makna, atau suatu pesan dianut secara sama.(Mulyana, 2000, p. 46) Sebuah teks kata Aart van Zoest, tak pernah lepas dari ideologi dan memiliki kemampuan untuk memanipulasi pembaca ke arah suatu ideologi.(Sobur, 2015, p. 60) Karena bahasa merupakan alat untuk mencapai tujuan tertentu. (Berger, 2014, p. 165) 
Tulisan yang dikemas oleh KH Abdurrahman Arroisi tak terlalu panjang, kurang lebih sekitar 500 kata pada setiap tulisannya. Meski singkat makna yang terkandung dari setiap kisahnya begitu mendalam. (Kompasiana, n.d.)

\section{Metode Penelitian}

Metode Penelitian yang penulis gunakan ialah Analisis Isi (Content Analysis). Analisis Isi (Content Analysis) adalah suatu teknik penelitian untuk membuat rumusan kesimpulan-kesimpulan dengan mengidentifikasi karakteristik spesifik secara sistematis dan objetif dari suatu teks.(Sadiah, 2015, p. 20)

\section{Hasil dan Pembahasan}

\section{A. Pesan Dakwah Kisah Dzulkarnain dalam Buku "30 Kisah Teladan" (Jilid} 1)

Pesan dakwah yang terkandung dalam buku 30 Kisah Teladan (Jilid I), dapat dilihat dalam kalimat atau dialog kemudian di analisis secara detail dan selanjutnya akan dipilih kedalam tiga kategori, yaitu Akidah, Akhlaq atau Syari'ah, dari 30 Kisah Teladan tersebut hanya 2 kisah yang menceritakan tentang Zulkarnain, yaitu memergoki cacat sang raja dan dikalahkan oleh nyamuk.

\section{Kisah "Memergoki cacat sang raja"}

Pesan dakwah yang yang pertama mengandung kategori Akhlaq tentang sifat pengecut, yaitu:

"Iskandar Zulkarnain yang Agung dari Makedonia adalah raja yang gagah perkasa dan keras wataknya. Ia paling benci kepada sifat-sifat pengecut. Namun, ia suka bertimbang rasa jika melihat kejujuran yang bersih."

Dari paragraf diatas "...Ia paling benci kepada sifat-sifat pengecut..." merupakan sifat yang dibenci oleh Zulkarnain, karena sifat tersebut adalah salah satu sifat tercela yang harus dihindari oleh umat Islam.

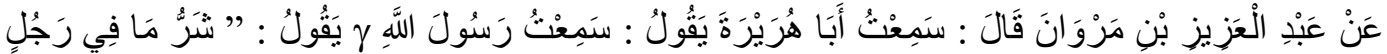

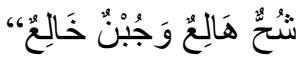

Dari Abdul Aziz bin Marwan, ia berkata, aku mendengar Abu Hurairah berkata, aku mendengar Rasulullah SAW bersabda: "Seburuk-buruk sifat yang ada pada seseorang adalah sifat pelit yang sangat pelit dan sifat pengecut yang sangat pengecut"(HR. Abu Daud, No. 2511, Ibnu Hibban, No. 808, Ahmad, 2:302., n.d.)

Sifat ini muncul ketika manusia takut menghadapi resiko, ketakutan ini bisa jadi muncul karena kekerdilan jiwa dan ketidaksanggupan untuk menghadapinya. Rasa takut inilah yang menggiring seorang hamba Allah menjadi seorang yang pengecut, 
lalu akhirnya berusaha untuk lari dari kenyataan. Oleh karena itu, Rasulullah senantiasa berdo'a:

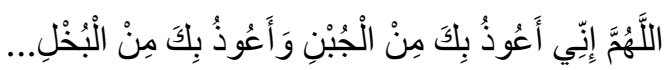

"Ya Allah aku berlindung kepada-Mu dari sifak kikir dan aku berlindung kepada-Mu dari sifat pengecut..." (HR. Al-Bukhari: No. 5897)

Pesan dakwah yang kedua mengandung kategori Akhlaq tentang berkata jujur walaupun pahit, yaitu:

"."Saya..... saya melihat...... Tuanku bertanduk......." jawab tukang kayu itu ketakutan. Ia sudah tahu hukuman apa yang bakal ditimpahkan atas dirinya. Namun, ia tidak mau berbohong untuk mengakatan tidak melihat tanduk di kepala Raja sebab ia selalu jujuur sepanjang hidupnya, betapapun pahit akibat kejujuran itu."

Dari paragraf diatas "...Namun, ia tidak mau berbohong untuk mengakatan tidak melihat tanduk di kepala Raja sebab ia selalu jujuur sepanjang hidupnya, betapapun pahit akibat kejujuran itu." Ini adalah kebiasaan si tukang kayu berkata jujur disepanjang hidupnya meskipun ia tahu resiko dari kejujuran tersebut dan perbuatan tukang kayu ini amatlah terpuji karena sesuai dengan apa yang disabdakan Nabi SAW:

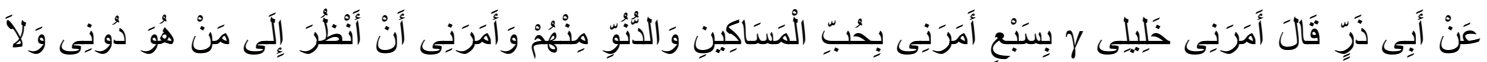

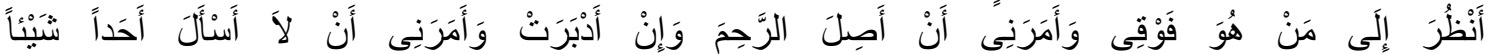

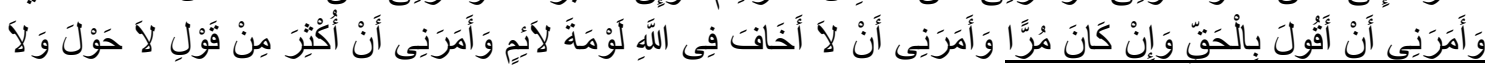

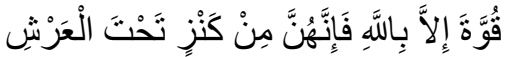

Dari Abu Dzaar, ia berkata, "Kekasihku Rasulullah $S A W$ memerintahkan tujuh hal padaku: "(1) mencintai orang miskin dan dekat dengan mereka, (2) beliau memerintah agar melihat pada orang di bawahku (dalam hal harta) dan janganlah lihat pada orang yang berada di atasku, (3) beliau memerintahkan padaku untuk menyambung tali silaturahim (hubungan kerabat) walau kerabat tersebut bersikap kasar, (4) beliau memerintahkan padaku agar tidak meminta-minta pada seorang pun, (5) beliau memerintahkan untuk mengatakan yang benar walau itu pahit, 6) beliau memerintahkan padaku agar tidak takut terhadap celaan saat berdakwa di jalan Allah, (7) beliau memerintahkan agar memperbanyak ucapan "laa hawla wa laa quwwata illa billah" (tidak ada daya dan upaya kecuali dengan pertolongan Allah), karena kalimat tersebut termasuk simpanan di bawah 'Arsy.”(HR. Ahmad, 5 :159)

Melihat pengertian diatas maka sifat tukang kayu tersebut termasuk ke dalam sifat jujur (sidiq) yang merupakan sifat dari para Nabi juga. Di dalam Al-Qur'an setidaknya Allah menyebutkan tiga Nabi yang memiliki sifat sidiq ini. Yang pertama adalah Nabi Ibrahim as (QS. Maryam: 41), yang kedua adalah Nabi Idris as (QS. Maryam: 56) dan yang ketiga adalah Nabi Yusuf as (QS. Yusuf: 51). 
Abdullah Bassam mengatakan Kemunafikan terbesar ialah seseorang menampakkan iman kepada Allah SWT, malaikat, kitab-kitab, para rasul, dam hari akhir, namun dalam batinnya menyembunyikan segala yang membatalkan keimanan. Sedangkan dasar dari kemunafikan ini adalah ciri-ciri yang telah disebutkan di dalam hadits.(Al-Asqalani, 2015, pp. 631-632)

Allah juga memasukkan sikap memenuhi janji adalah salah satu ciri orang bertakwa. Allah berfirman:

"Kebajikan itu bukanlah menghadapkan wajahmu ke arah Timur dan ke Barat, tetapi kebajikan itu ialah (kebajikan) orang yang beriman kepada Allah, Hari Akhir, para malaikat, kitab-kitab, dan nabi-nabi, dan memberikan harta yang dicintainya kepada kerabat, anak yatim, orang-orang miskin, orang-orang yang dalam perjalanan (musafir), peminta-minta, dan untuk memerdekakan hamba sahaya, yang melaksanakan shalat dan menunaikan zakat, orang-orang yang menepati janji apabila berjanji, dan orang yang sabar dalam kemelaratan, penderitaan dan pada masa peperangan. Mereka itulah orang-orang yang benar, dan mereka itulah orangorang yang bertakwa. ”(QS. Al-Baqarah: 177)

Di samping itu Allah juga menjamin keberuntungan (falah) bagi orang-orang mukmin. yang menjaga amanah dan memenuhi janji di dunia dan menjadi penghuni surga Firdaus di akhirat kelak. (Antonio, 2013, pp. 31-32)

"Sungguh beruntung orang-orang yang beriman ... Dan (sungguh beruntung) orang yang memelihara amanah-amanahnya dan janjinya ... Mereka itulah orang yang akan mewarisi, (yakni) yang akan mewarisi (surga) Firdaus. Mereka kekal di dalamnya."(QS. Al-Mu'minun: 1-11)

Karakter tukang kayu tersebut juga sesuai dengan teladan Nabi SAW dalam memenuhi janji, seperti dalam suatu dialog antara Heraklius, Pemimpin Romawi, dengan Abu Sufyan, sebelum dia masuk Islam, Heraklius bertanya, "Apa yang diperintahkan Nabi itu?" Abu Sufyan menjawab, “ia menyuruh kami untuk menyembah hanya kepada Allah SWT dan tidak menyekutukan-Nya dengan sesuatu apapun. Ia melarang kami untuk mengikuti para pendahulu dan nenek moyang kami yang menyembah berhala. Ia juga memerintahkan shalat, sedekah (zakat), menjaga kesucian diri, memenuhi janji, dan menyampaikan amanat."

Riwayat ini menjelaskan bahwa salah satu ajaran utama Nabi SAW adalah memenuhi janji. Tidak ada yang keberatan dengan ajaran-ajaran beliau yang berhubungan dengan akhlak. Mereka hanya keberatan dengan ajaran untuk menyembah Allah SWT dan tidak menyekutukan-Nya dengan yang lain. Heraklius pun tidak keberatan dengan ajaran beliau tersebut dan melihat tidak ada yang salah dengan semua ajaran Muhammad SAW.(Antonio, 2013, pp. 34-35) 
Pesan dakwah yang keempat mengandung kategori Akhlaq tentang Pemimpin yang bijaksana, yaitu:

"Raja, selaku seorang pemimpin yang bijaksana walaupun keras sifat dan wataknya, ingin tahu apakah orang ini tidak berdusta. Ditanyakan kepada sebagian masyarakat yang mendengar berita itu, dari mana mereka tahu cacat Raja. Ternyata betul. Memang dari seekor burung beo yang terbang kesana kemari sambil mengoceh: "Hai kayu, Raja Iskandar punya tanduk di kepalanya.""

Dari paragraf diatas "Raja, selaku seorang pemimpin yang bijaksana walaupun keras sifat dan wataknya, ingin tahu apakah orang ini tidak berdusta." Inilah sifat seharusnya yang harus dimiliki oleh seorang Pemimpin, baik keluarga atau pun pemerintahan, bijak dalam memutuskan segala sesuatu tidak boleh sewenangwenangnya karena segala keputusan akan dimintai pertanggung jawabannya, Nabi SAW bersabda:

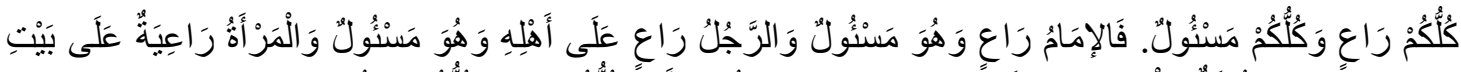

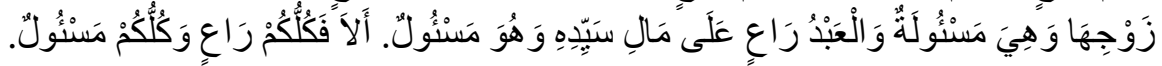

Setiap kalian adalah pemimpin, dan setiap kalian akan dimintai pertanggungjawabannya. Seorang imam adalah pemimpin dan akan dimintai pertanggungjawabannya. Seorang laki-laki adalah pemimpin atas keluarganya dan ia akan dimintai pertanggungjawabannya. Seorang wanita adalah pemimpin atas rumah suaminya, dan ia pun akan dimintai pertanggungjawabannya. Seorang budak juga pemimpin atas harta tuannya dan ia juga akan dimintai pertanggungjawabannya. Sungguh setiap kalian adalah pemimpin dan setiap kalian akan dimintai pertanggungjawabannya.(HR. al-Bukhari, No. 4789)

Pesan dakwah yang kelima mengandung kategori Akhlaq tentang Kejujuran yang menghantarkan pada kebaikan, yaitu:

"Lantaran terbukti tukang kayu itu jujur dan Raja suka kepada kejujuran, maka tukang kayu itu dibebaskan dari segala hukuman, bahkan diangkat menjadi pegawai kerajaan yang dipercaya."

Dari paragraf diatas bahwa setiap kejujuran pasti akan menghantarkan pada kebaikan meskipun awalnya akan terasa pahit, begitulah yang terjadi kepada si tukang kayu, dia tetap berkata jujur meskipun ancamannya nyawa sekalipun karena ia tahu kejujuran pasti akan menghantarkan dirinya pada kebaikan dan terbuktilah keujujurannya itu dapat membebaskan dirinya dari hukuman bahkan diangkat menjadi pegawai kerajaan. Tapi sebaliknya, ketika kebohonganlah yang ditampakkan maka yang ada akan menghantarkan dirinya pada kesengsaraan. Nabi SAW bersabda: 


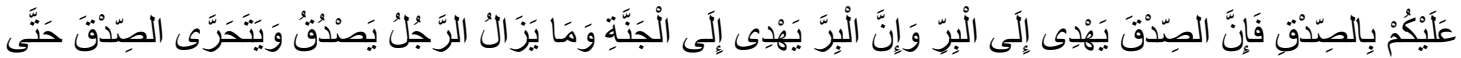

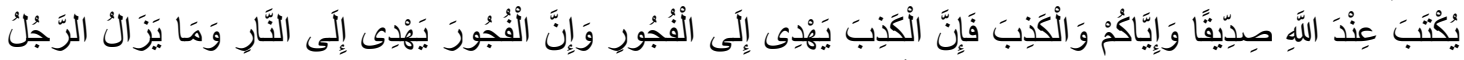

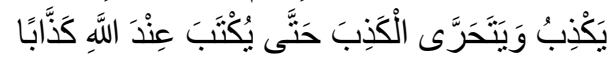

"Hendaklah kalian senantiasa berlaku jujur, karena sesungguhnya kejujuran akan megantarkan pada kebaikan dan sesungguhnya kebaikan akan mengantarkan pada surga. Jika seseorang senantiasa berlaku jujur dan berusaha untuk jujur, maka dia akan dicatat di sisi Allah sebagai orang yang jujur. Hati-hatilah kalian dari berbuat dusta, karena sesungguhnya dusta akan mengantarkan kepada kejahatan dan kejahatan akan mengantarkan pada neraka. Jika seseorang sukanya berdusta dan berupaya untuk berdusta, maka ia akan dicatat di sisi Allah sebagai pendusta."

Abdullah Bassam mengatakan bahwa hadits ini berisi perintah jujur, karena kejujuran menunjukkan kebajikan (Bir) yang terhimpun padanya kebaikan. Kebajikan adalah jalan yang lurus menuju surga. Firman Allah SWT: "Sesungguhnya orangorang yang banyak berbakti benar-benar dalam surga yang penuh kenikmatan” (QS. Al-Infithar, 82: 13). Hadits ini menunjukkan larangan berdusta, karena dusta menunjukkan kefasikan dan kemaksiatan.(Al-Asqalani, 2015, p. 643)

\section{Kisah "Dikalahkan oleh nyamuk"}

Pesan dakwah yang pertama mengandung kategori Akidah tentang kematian tidak membawa apa-apa, yaitu:

“Araklah kereta itu kembali ke Makedonia dengan lambat-lambat, agar bangsa-bangsa yang pernah kutaklukan disepanjang perjalanan, menyaksikan dengan mata kepala sendiri betapa Iskandar yang agung, yang perkasa, yang selalu menang perang, pada waktu matinya tidak membawa apa-apa. Tidak sebongkah emas pun digenggamnya dari harta rampasan yang begitu banyak."

Dari paragraf diatas "betapa Iskandar yang agung, yang perkasa, yang selalu menang perang, pada waktu matinya tidak membawa apa-apa." Menunjukkan bahwa ketika seseorang meninggal dunia, dia tidak akan membawa apa-apa meskipun ketika dimasa hidupnya dia dikenal sebagai orang yang kaya atau orang yang sangat luas kekuasaannya, kecuali tiga perkara. Rasulullah SAW bersabda:

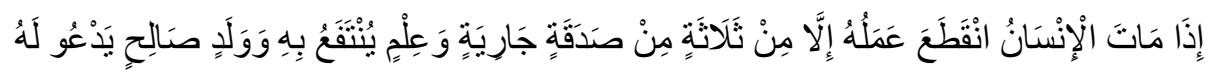

"Jika seseorang meninggal dunia, maka terputuslah amalannya kecuali tiga perkara (yaitu): sedekah jariyah, ilmu yang dimanfaatkan, dan do'a anak yang sholeh." ( HR. Muslim no. 1631)

Hadits diatas menerangkan bahwa hanya tiga hal yang amalnya akan terus mengalir meskipun sudah meninggal yaitu sedekah jariyah, ilmu yang dimanfaatkan, 
dan do'a anak yang sholeh. Selain dari ketiga hal tersebut baik itu harta, keluarga, jabatan dan sebagainya akan ditinggalkan.

Pesan dakwah yang kedua mengandung kategori Akhlaq tentang sifat sombong, yaitu:

"Supaya para raja, para penguasa, dan para panglima dibelakangku kelak, tidak akan sombong dengan kekuasaan mereka."

Dari paragraf diatas menunjukkan bahwa masih banyak raja, penguasa atau pun panglima perang yang sombong dengan kekuasaannya, lalu meggunakan kekuasaan tersebut untuk mendzolimi orang lain padahal semua jabatan atau gelar tersebut hanyalan titipan dari Allah SWT yang harus dijaga dengan sebaik mungkin. Allah SWT berfirman:

$$
\text { لِلَّهِ ما فِي السَّمَاو اتِ وَمَا فِي الأَرْضِ }
$$

"Kepunyaan Allah-lah segala apa yang ada di langit dan apa yang ada di bumi..." (QS. Al-Baqarah: 284)

Maka jelas dengan ayat tersebut, semua yang kita miliki hanyalah milik Allah SWT semata, tidak ada ruang untuk sombong dengan apa yang kita miliki.

Dan Allah memperigatkan kita di ayat yang lain tentang jangan berlaku sombong, seperti nasihat Luqman dibawah ini:

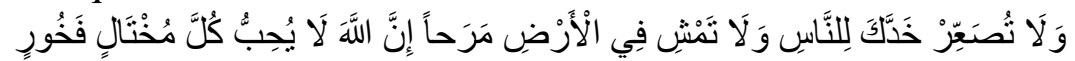

"Dan janganlah kamu memalingkan mukamu dari manusia (karena sombong) dan janganlah kamu berjalan di muka bumi dengan angkuh. Sesungguhnya Allah tidak menyukai orang-orang yang sombong lagi membanggakan diri." (QS. Luqman: 18)

Karena sombong juga salah satu sifat yang dimiliki syetan, Allah SWT berfirman:

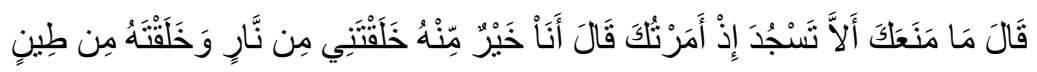

Allah berfirman: "Apakah yang menghalangimu untuk bersujud (kepada Adam) di waktu Aku menyuruhmu?" Menjawab iblis "Saya lebih baik daripadanya: Engkau ciptakan saya dari api sedang dia Engkau ciptakan dari tanah". (QS. Al-A'raf: 12, lihat juga QS. Al-Hijr: 32-33.)

Itulah bentuk sombongnya syetan, ia tidak mau bersujud kepada Adam, padahal itu merupakan perintah Allah. Ia merasa bahwa dirinya lebih baik daripada Adam karena diciptakan Allah dari api sedangkan Adam diciptakan dari tanah.(Zakaria, 2018, p. 129)

Dan konsekuensi dari sifat sombong ini adalah tidak akan masuk surga. Nabi SAW bersabda:

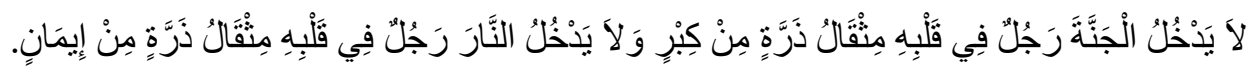

"Tidak akan masuk surga orang yang di hatinya ada kesombongan meskipun seberat biji sawi dan tidak akan masuk neraka orang yang di hatinya ada keimanan meskipun seberat biji sawi."(HR. Ahmad, No. 3947) 
Pesan dakwah yang ketiga mengandung kategori Akidah tentang kematian tidak bisa dihindari, yaitu:

\section{"Sebab, ternyata ujung semua kebesaran, keagungan, adalah kematian dan manusia tidak beraya untuk menghindarinya."}

Dari paragraf diatas menunjukkan bahwa sehebat apapun manusia tidak akan bisa menghindari kematian, karena kematian adalah takdir yang sudah ditentukan ketika kita masih didalam kandungan. Allah SWT berfirman:

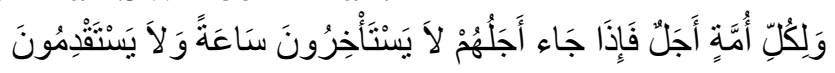

"Tiap-tiap umat mempunyai batas waktu; maka apabila telah datang waktunya mereka tidak dapat mengundurkannya barang sesaatpun dan tidak dapat (pula) memajukannya. ”(QS. Al-A'raf: 34, lihat juga QS. An-Nisa: 78, Ali Imran: 145, 185, Al-Anbiya: 35)

Ayat diatas menjelaskan bahwa kematian itu tidak dapat diprediksi, oleh karena itu kita harus mempersiapkannya, jangan sampai ketika kematian datang kita dalam keadaan su'ul khatimah.

Maka Allah SWT telah mengingatkan didalam Al-Qur'an bentapa pentingnya mendapat husnul khatimah itu kepada semua orang yang beriman. Allah SWT berfirman:

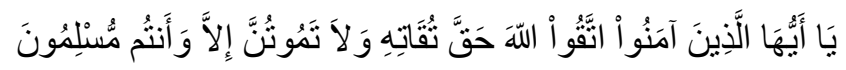

"Hai orang-orang yang beriman, bertakwalah kepada Allah sebenar-benar takwa kepada-Nya; dan janganlah sekali-kali kamu mati melainkan dalam keadaan beragama Islam."'(QS. Ali Imran: 102, lihat juga QS. Al-Hijr: 99)

Oleh karena itulah, perintah untuk tetap bertakwa dan beribadah masih terus berlanjut hingga maut menjelang.

Ini tidak lan agar husnul khatimah bisa diraih. Rasulullah SAW telah menjelaskan bahwa ada sebagian orang yang berusaha melakukan berbagai bentuk ketaatan dan menghindari segala bentuk kemaksiatan. Upayanya itu dilakukannya terus-menerus dalam jangka waktu yang lama sepanjang hidupnya. Namun beberapa saat menjelang kematiannya, ia malah melakukan berbagai kesalahan dan bermacam kemaksiatan. Keburukan pada akhir hidupnya ini jutru menjadi penyebab ia mendapatkan su'ul khatimah.

\section{B. Pesan Dakwah Kisah Dzulkarnain yang paling dominan dalam Buku "30 Kisah Teladan" (Jilid 1)}

Berikut ini adalah pesan dakwah kisah Dzulkarnain yang paling dominan dalam buku "30 Kisah Teladan" (jilid 1):

\section{Pesan Akhlak}

Pesan Akhlak terletak di posisi pertama, pesan ini paling dominan di kisah Dzulkarnain. Berdasarkan hasil penelitian secara sistematik, maka ada 6 pesan akhlak yang berkaitan dengan mengatur hubungan antar manusia yaitu sifat pengecut, sifat sombong, berkata jujur walau pahit, kejujuran menghantarkan kebaikan, janji harus ditepati, dan pemimpin bijaksana. 


\section{Pesan Akidah}

Pesan Akidah terletak di posisi kedua setelah syari'ah, dimana akidah itu berhubungan dengan rukun iman yang enam. Dan berdasarkan hasil penelitian secara sistematik, hanya ada 2 pesan Akidah yang berkaitan dengan iman kepada qadha dan qadhar Allah yaitu kematian tidak membawa apa-apa dan kematian tidak bisa dihindari.

\section{Pesan Syari'ah}

Pesan Akidah terletak di posisi terakhir setelah akhlak dan akidah, dimana syari'ah itu berhubungan dengan Ibadah dan Mu'amalah. Dan berdasarkan hasil penelitian secara sistematik, tidak ada satu pun kalimat yang mengandung pesan syari'ah pada kisah Dzulkarnain tersebut.

\section{Kesimpulan}

Setelah menjelaskan dan menganalisa data pada bab-bab sebelumnya, maka pada bab penutup ini peneliti mengambil kesimpulan dari rumusan masalah sebelumnya, yaitu: Analisis Isi Pesan Dakwah Raja Dzulkarnain dengan kisahnya yang berjudul memergoki cacat sang Raja dan Dikalahkaan oleh nyamuk, antara lain:

1. Dalam penelitian, terdapat pesan akidah yang berisi tentang kematian. Terdapat pula pesan akhlak yang berisi tentang akhlak mahmudah dan akhlak madzmumah. Namun didalam kisah ini peneliti tidak menemukan pesan-pesan syari'ah, tapi didominasi oleh pesan akhlak. Dan pesan yang paling menonjol dalam buku ini adalah pesan akhlak. Pesan-pesan yang disampaikan cenderung membahas tentang pesan-pesan akhlak. Dan isi pesan yang ingin disampaikan dalam kisah dzulkarnain ini adalah tentang bagaimana kita berakhlakul karimah meskipun dalam keadaan genting dan bagaimana kita mempersiapkan Qadha dan Qadar Allah yang sudah ditentukan.

2. Dari dua kisah dzulkarnain, pesan akhlaklah yang paling dominan yakni memiliki 6 pesan yaitu pesan sifat pengecut, sifat sombong, berkata jujur walau pahit, kejujuran menghantarkan kebaikan, janji harus ditepati, dan pemimpin bijaksana. Lalu 2 pesan akidah, yaitu pesan kematian tidak membawa apa-apa dan kematian tidak bisa dihindari.

\section{Bibliografi}

Al-Asqalani, I. H. (2015). Bulughul Maram Takhtij dan Tahqiq.

Antonio, M. S. (2013). Ensikopedia Propetic Leadership\&Management Wisdom: Amanah Inter_Personal Capitl.

Berger, C. R. (2014). Handbook Ilmu Komunikasi.

HR. Abu Daud, No. 2511, Ibnu Hibban, No. 808, Ahmad, 2:302. (n.d.). 
Muhtadi, A. S. (2012). Komunikasi Dakwah.

Mulyana, D. (2000). Ilmu komunikasi: suatu pengantar. Remaja Rosdakarya.

Sadiah, D. (2015). Metode penelitian dakwah. Bandung: PT Remaja Rosdakarya.

Sobur, A. (2015). Analisis Teks Media.

Zakaria, A. (2018). Prinsip-Prinsip Akhlaq Mulia Jilid Kesatu.

https://almanhaj.or.id/11476-dzulqarnain-penguasa-yang-adil.html. (n.d.).

https://www.kompasiana.com/ikromzzzt/5b0d2645ab12ae7fbc6d07f3/penulisdalam-anonimitas-sosol-k-h-abdurrahman-arroisi-yang-mengagumkan?page=all . 